\title{
Identification of candidate genes conferring tolerance to aluminum stress in Pinus massoniana inoculated with ectomycorrhizal fungus
}

\author{
Haiyan Liu ${ }^{1,2}$, Houying Chen ${ }^{1}$, Guijie Ding ${ }^{1 *}$, Kuaifen Li ${ }^{1}$ and Qifei Ren ${ }^{2}$
}

\begin{abstract}
Background: Pinus massoniana Lamb. is an important afforestation tree species with high economic, ecological and medicinal values. Aluminum (Al) toxicity driven by soil acidification causes dieback of $P$. massoniana plantations. Previous studies showed that ectomycorrhizal fungi alleviate Al stress damages in Pinus, but the underlying molecular mechanisms and key genes induced by ectomycorrhizal fungi inoculation under Al stress in Pinus have not been explored. Herein, we applied Al stress for 60 days to P. massoniana seedlings inoculated with Suillus luteus (SL) and those non-inoculated. Then, we compared their growth parameters and transcriptome in order to detect candidate genes induced by SL conferring Al tolerance in P. massoniana.
\end{abstract}

Result: Our results showed that SL inoculation confers Al stress tolerance in P. massoniana through improved growth performance, strong antioxidant enzyme activities and reduced malondialdehyde accumulation as compared to noninoculated seedlings. Transcriptome sequencing further supported these findings as very few genes (51 genes) were transcriptionally altered by Al in SL inoculated plants as compared to non-inoculated plants ( 2140 genes). We identified three core genes ( $\operatorname{cox} 1, \operatorname{cox} 3$ and $\mathrm{Nd}$ 1) that were strongly up-regulated by Al in the SL inoculated plants but were down-regulated in the non-inoculated plants. We also identified 42 genes specifically regulated by SL inoculated plants under Al stress, which are involved in a wide range of biological processes such as antioxidative response, transporters, hormone signaling and plant pathogen infection responses.

Conclusions: Altogether, our data suggest that SL inoculation induces priming of key stress response pathways and triggers specific genes that efficiently alleviate Al stress effects in $P$. massoniana. The candidate genes resources generated in this study are of utmost importance for functional characterization and molecular studies aiming at improving Al tolerance in plants.

Keywords: Aluminum toxicity, Afforestation, Gene expression, Ectomycorrhizal fungus, Pinus massoniana

\footnotetext{
* Correspondence: gidinggzu@126.com

${ }^{1}$ College of Forestry, Guizhou University/Institute for Forest Resources \&

Environment of Guizhou, Guiyang 550025, Guizhou, China

Full list of author information is available at the end of the article
}

(c) The Author(s). 2020 Open Access This article is licensed under a Creative Commons Attribution 4.0 International License, which permits use, sharing, adaptation, distribution and reproduction in any medium or format, as long as you give appropriate credit to the original author(s) and the source, provide a link to the Creative Commons licence, and indicate if changes were made. The images or other third party material in this article are included in the article's Creative Commons licence, unless indicated otherwise in a credit line to the material. If material is not included in the article's Creative Commons licence and your intended use is not permitted by statutory regulation or exceeds the permitted use, you will need to obtain permission directly from the copyright holder. To view a copy of this licence, visit http://creativecommons.org/licenses/by/4.0/ The Creative Commons Public Domain Dedication waiver (http://creativecommons.org/publicdomain/zero/1.0/) applies to the data made available in this article, unless otherwise stated in a credit line to the data. 


\section{Background}

Pinus massoniana Lamb. is an important afforestation tree species belonging to the Pinaceae family. It is native to southern China and is one of the dominant species for forest plantations in China [1]. P. massoniana is a pioneer species, highly tolerant to environmental stresses and grows well in barren areas and metal-contaminated soils [2-6]. It not only contributes to meeting the growing demand of wood products but also reduces pressures on natural forests and significantly contributes to restoration of degraded soils [7-10]. Besides these economic and ecological values, several studies have demonstrated the pharmacological properties of $P$. massoniana bark and needles for the treatment of rheumatism, intestinal parasites, hypertension, neurasthenia, skin complaints and cancer [11-14].

Pinus species, including P. massoniana, are natural hosts for diverse ectomycorrhizal fungal species [15-19]. It has been reported that ectomycorrhizal symbiosis establishment in the root system confers improved growth performance and tolerance to biotic and abiotic stress in host plants [20-22]. This has been ascribed to the improved nutrient and water acquisition, photosynthetic rate and enhancement of the antioxidant systems and immune system in the hosts [23, 24]. In Pinus, previous studies have shown that ectomycorrhizal fungi improve plant growth and tolerance to drought stress, salinity stress, low-phosphorous stress, heavy metals toxicity, etc. [4, 6, 25-28].

Aluminum $(\mathrm{Al})$ toxicity driven by soil acidification is a long-lasting problem causing forest dieback in many regions of the world [29], particularly in China where natural and forest plantations are declining [30]. Acid rain and anthropogenic soil acidification caused by long-range air pollution and intensive uses of acid-forming fertilizers create nutrient depletion in the soil and accelerate bioavailability of toxic elements such as $\mathrm{Al}^{3+}$ [31-33]. Von Uexkuell and Mutert estimated early in 1995 that acid soils cover more than $70 \%$ of potential arable soils [34] but this value could be higher nowadays with the evergrowing industrialization and intensive agriculture. High amount of $\mathrm{Al}$ in the soil inhibits plant root growth and decreases nutrient and water uptake $[35,36]$, leading to significant reductions of plant productivity. It also increases the levels of reactive oxygen species (ROS), leading to lipid peroxidation and cell death [37]. Deciphering the mechanisms of $\mathrm{Al}$ tolerance in plants has catalyzed numerous studies and our understanding on the topic is increasing. For example, the exclusion and internal detoxification of $\mathrm{Al}$ have been demonstrated in several plants [38-40] and some related genes such as the aluminum activated malate transporter (ALMT) and multidrug and toxic compound extrusion (MATE) have been discovered [40-45].

In forest tree species, some degrees of tolerance to $\mathrm{Al}$ toxicity have been observed with a variation among species and genotypes [46-48]. For example, Betula pendula is able to tolerate $\mathrm{Al}$ concentration up to $3 \mathrm{mM}$ [49], while Liu and Liu [47] found that the lowest concentration of aluminum toxicity in P. massoniana was $0.15 \mathrm{mM}$. Besides the intrinsic capacity to exclude $\mathrm{Al}$ from root of each plant species, ectomycorrhizal symbiosis establishment in the root system can provide another layer of defensive force against $\mathrm{Al}$ stress damages to the host plant. In support to this idea, previous studies have shown that ectomycorrhizal fungi alleviate Al stress damages in Pinus [50, 51]. However, the underlying molecular mechanisms and key genes induced by ectomycorrhizal fungi inoculation under Al stress in Pinus have not been explored.

In a preliminary experiment, we found that inoculation with the ectomycorrhizal fungus species Suillus luteus (SL) promotes $P$. massoniana growth and imparts $\mathrm{Al}$ stress tolerance. We therefore designed the present study to explore the transcriptome of SL inoculated plants and non-inoculated plants under $\mathrm{Al}$ stress in order to detect candidate genes mediated by SL conferring $\mathrm{Al}$ stress tolerance in P. massoniana.

\section{Result \\ Morpho-biochemical responses to aluminum stress with or without ectomycorrhizal fungus inoculation}

P. massoniana seedlings were subjected to Aluminum (Al) stress for 60 days with Suillus luteus (SL) inoculation or without inoculation (CK). Several morpho-biochemical parameters were investigated. As shown in Fig. 1a, the root density of the seedlings inoculated with the ectomycorrhizal fungus (SL) was higher as compared to non-inoculated seedlings (CK) independently of the $\mathrm{Al}$ concentrations, demonstrating the successful inoculation in our experiment. Quantitative analysis of root traits showed that $\mathrm{Al}$ treatment reduced all root traits. However, SL inoculation improved the root surface area, average root diameter and root number traits under $\mathrm{Al}$ treatment as compared to $\mathrm{CK}$ plants (Table 1). Without $\mathrm{Al}$, the seedling height was slightly increased in SL inoculated plants as compared to CK but not significantly (Fig. 1b). Other traits such as shoot fresh weight (SFW), root fresh weight (RFW), shoot dry weight (SDW), root dry weight (RDW) were significantly improved by SL inoculation (Fig. 1c). With $0.4 \mathrm{mmol} \mathrm{L}^{-1}$ $\mathrm{Al}$ application, all morphological traits were reduced independently of SL inoculation (Fig. $1 \mathrm{~b}, \mathrm{c}$ ), indicating that $\mathrm{Al}$ affects $P$. massoniana seedling growth. Noteworthy, all morphological traits were significantly higher in SL inoculated plants than in CK plants, implying that SL improves P. massoniana tolerance to $\mathrm{Al}$ stress (Fig. 1b, c).

Under stress conditions, plants accumulate excessive levels of reactive oxygen species (ROS). Malondialdehyde (MDA) content is associated with lipid peroxidation via an increased generation of ROS [52]. A high level of MDA is an indicator of a high level of stress damage. We measured the MDA content in needle samples from the four 


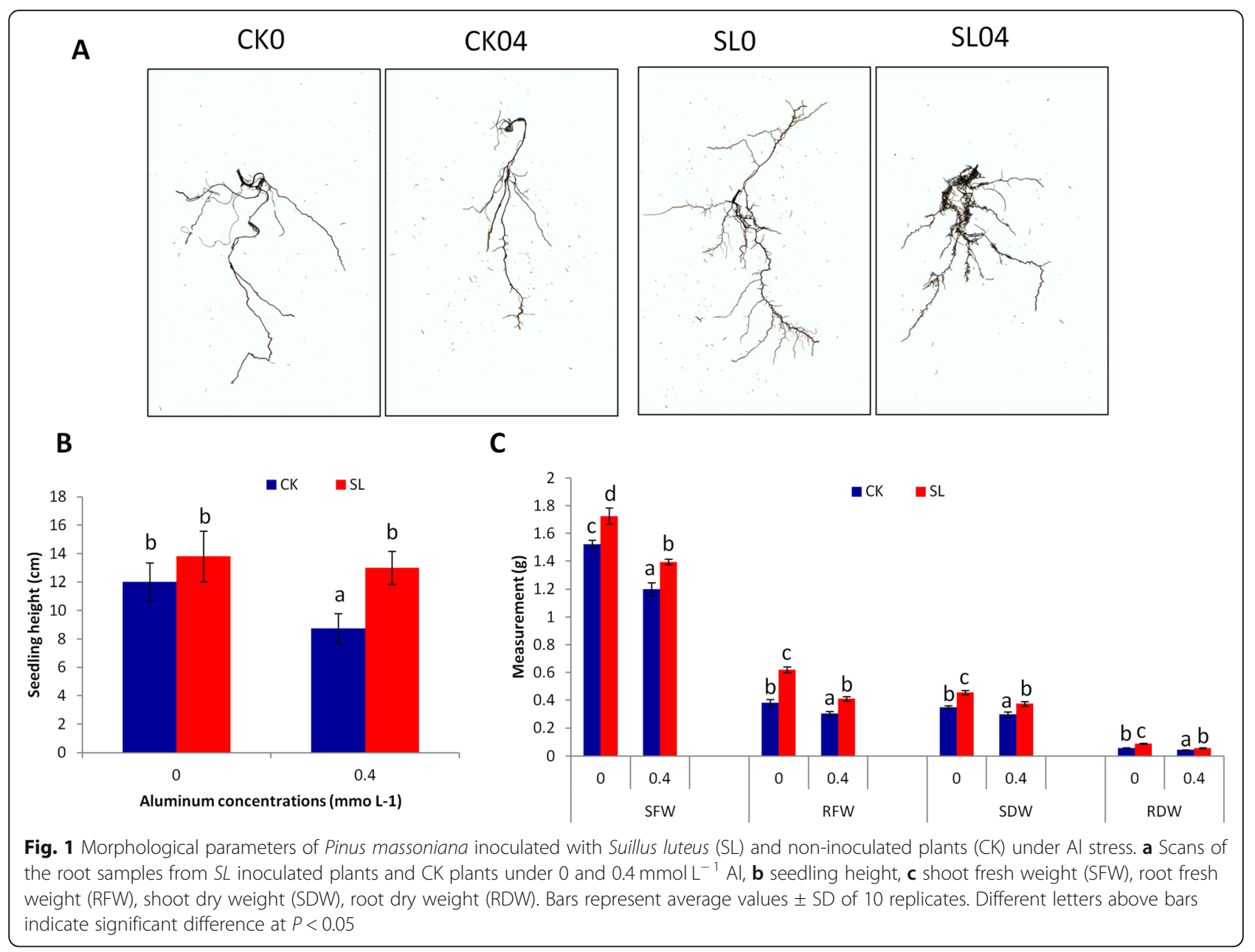

treatments (Fig. 2a). Without $\mathrm{Al}$ stress, similar levels of MDA could be observed in CK and SL inoculated plants. However under $\mathrm{Al}$ stress, although MDA content increased in both CK and SL inoculated plants, a significantly higher MDA content was measured in CK plants compared to SL inoculated plants. This result suggests that CK plants suffered from oxidative damages under $\mathrm{Al}$ stress while SL inoculation helped to keep MDA level in a normal range.

To effectively combat ROS excessive accumulation in plants, a strong activation of antioxidant enzymes such as superoxide dismutase (SOD) and peroxidase (POD) is essential [53]. In this study, we observed that both CK and SL inoculated plants increased their SOD and POD activities under Al stress. However, significantly higher SOD and POD activities were noticed in SL inoculated plants as compared to CK plants (Fig. 2b, c). Altogether, our results suggest that $\mathrm{SL}$ inoculation enhances $\mathrm{Al}$ stress tolerance in P. massoniana through enhanced antioxidant enzymes activity.

\section{Portray of the transcriptome sequencing and assembly}

In order to get insight into the molecular basis of $\mathrm{Al}$ stress tolerance induced by SL inoculation in P. massoniana, we sequenced the transcriptome of needle samples from the four treatments. With three replicates in each treatment, 12 samples in total were sequenced, yielding on average 54,226,624 raw reads per sample (Table 2). After cleaning, we obtained $89 \mathrm{~Gb}$ data with Q30 quality

Table 1 Characterization of root traits in Pinus seedlings. Different letters display significant difference at $P<0.05$

\begin{tabular}{lllll}
\hline Samples & Main root length $(\mathbf{c m})$ & Root surface area $\left.\mathbf{( c m}^{2}\right)$ & Average root diameter $(\mathbf{m m})$ & Root number \\
\hline CKO & $6.24 \pm 1.41 \mathrm{a}$ & $0.73 \pm 0.8 \mathrm{a}$ & $0.36 \pm 0.10 \mathrm{~b}$ & $50.75 \pm 8.04 \mathrm{~b}$ \\
CK04 & $3.98 \pm 0.80 \mathrm{~b}$ & $0.39 \pm 0.12 \mathrm{c}$ & $0.20 \pm 0.05 \mathrm{c}$ & $30.00 \pm 8.11 \mathrm{c}$ \\
SL0 & $5.41 \pm 1.30 \mathrm{a}$ & $0.77 \pm 0.08 \mathrm{a}$ & $0.55 \pm 0.07 \mathrm{a}$ & $63.25 \pm 11.45 \mathrm{a}$ \\
SL04 & $3.64 \pm 0.70 \mathrm{~b}$ & $0.52 \pm 0.15 \mathrm{~b}$ & $0.39 \pm 0.05 \mathrm{~b}$ & $47.00 \pm 9.90 \mathrm{~b}$ \\
\hline
\end{tabular}



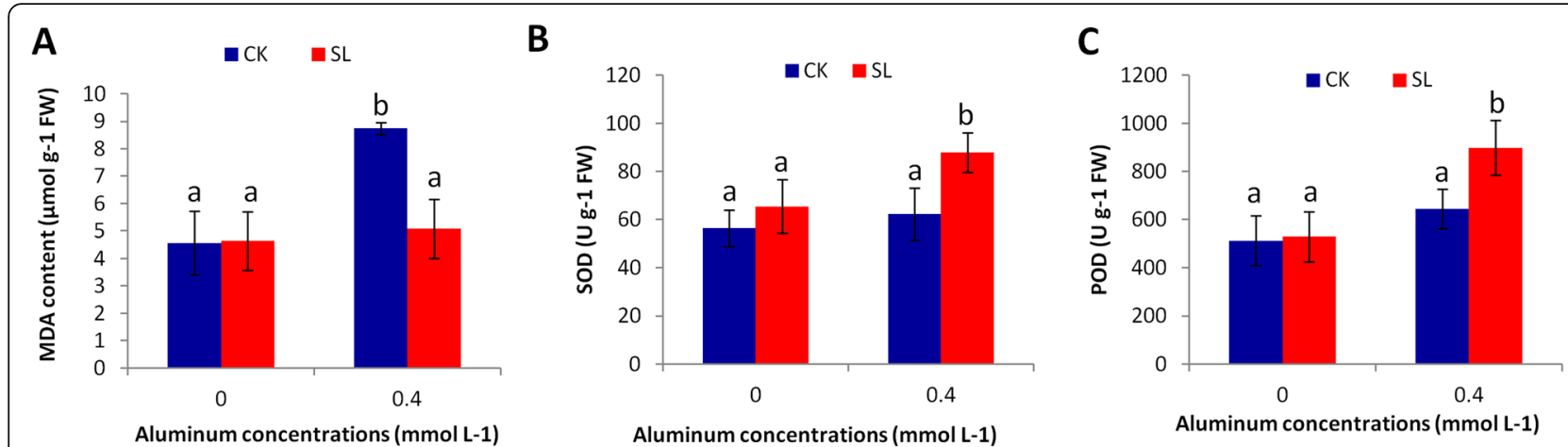

Fig. 2 Enzyme activities and malondialdehyde (MDA) content in Pinus massoniana inoculated with Suillus luteus (SL) and non-inoculated plants (CK) under Al stress. a MDA content, $\mathbf{b}$ Superoxide dismutase (SOD) activity, $\mathbf{c}$, peroxidase (POD) activity in plants grown under 0 and $0.4 \mathrm{mmol}$ $\mathrm{L}^{-1}$ Al. Bars represent average values \pm SD of 10 replicates. Different letters above bars indicate significant difference at $P<0.05$

score higher than $93 \%$ and error rate lower than 0.03 . The clean data were de novo assembled as the reference gene set using the Trinity software and 145,434 unigenes spanning 90,173,863 bp long were obtained with a mean length of $620 \mathrm{bp}$ and a N50 of $1022 \mathrm{bp}$ long. The unigene length distribution is shown in Fig. 3a. The unigenes were annotated in five different databases including NR, SwissProt, PFAM, GO and KO, with $67 \%$ of the total unigenes annotated in at least one database (Table 3).

The gene expression was estimated with fragments per kilobase of exon per million fragments mapped (FPKM) and FPKM value $>1$ was used as a threshold to determine the expressed genes (Fig. 3b). Using the FPKM data, we performed a principal component analysis (PCA) to check the clustering pattern of the samples from the four treatments and their replicates. As shown in Fig. 3c, PC1 and PC2 together contributed to over $66 \%$ of the global variation. PC1 clearly separated $\mathrm{Al}$ treated samples and the non treated samples. By PC2, we could observe a separation between SL inoculated samples from the noninoculated samples. In addition, the replicates of each treatment were found closely clustered, showing that the quality of the transcriptome sequencing was good enough to proceed to further analyses.

\section{Differentially expressed genes}

In order to identify the differentially expressed genes (DEG), we cross-compared the gene count between treatments using following screening criteria: $\mid \log 2$ fold change $\geq 2$ [54], and false discovery rate (FDR) correction set at $P<0.05$. In total, 2140, 1718, 17 and 51 DEGs were detected in CK04_vs_CK0, SL0_vs_CK0, SL04_vs_ CK04 and SL04_vs_SL0, respectively (Fig. 3d). Gene ontology enrichment analysis of the DEGs showed various biological pathways (metabolic process, photosynthesis, oxido-reduction process, nucleotide binding, etc.) affected by $\mathrm{Al}$ and SL treatments (Figure S1). Kyoto Encyclopedia of Genes and Genomes enrichment analyses of the DEGs showed that phorphyrin and chlorophyll metabolism, zeatin biosynthesis were the most enriched pathways affected by $\mathrm{Al}$ and SL treatments (Figure S2). The comparison CK04_vs_CKO provides

Table 2 Statistics of the transcriptome sequencing and quality check

\begin{tabular}{|c|c|c|c|c|c|c|c|}
\hline Samples & Raw_reads & Clean_reads & Clean_bases (Gb) & Error (\%) & Q20 (\%) & Q30 (\%) & GC (\%) \\
\hline CK01 & $50,686,474$ & $50,295,380$ & 6.99 & 0.02 & 97.87 & 93.76 & 47.07 \\
\hline CKO2 & $50,394,888$ & $50,015,274$ & 6.94 & 0.02 & 97.95 & 93.92 & 47.14 \\
\hline CK03 & $61,303,972$ & $60,958,750$ & 8.43 & 0.029 & 97.99 & 94.03 & 47.34 \\
\hline CK041 & $50,440,018$ & $50,157,384$ & 6.86 & 0.029 & 97.96 & 94 & 47.7 \\
\hline CK042 & $57,788,340$ & $57,453,616$ & 7.9 & 0.029 & 97.87 & 93.75 & 47.58 \\
\hline CK043 & $58,747,552$ & $58,404,162$ & 8.02 & 0.029 & 97.87 & 93.76 & 47.68 \\
\hline SL01 & $57,381,552$ & $57,042,586$ & 7.8 & 0.029 & 97.99 & 94.08 & 47.95 \\
\hline SLO2 & $63,618,448$ & $63,275,858$ & 8.73 & 0.029 & 97.95 & 93.96 & 47.37 \\
\hline SLO3 & $59,962,230$ & $59,628,096$ & 8.24 & 0.029 & 97.96 & 93.93 & 47.35 \\
\hline SL041 & $43,256,016$ & $42,968,462$ & 5.96 & 0.029 & 97.84 & 93.67 & 46.98 \\
\hline SL042 & $46,580,296$ & $46,369,104$ & 6.43 & 0.02 & 98.15 & 94.34 & 47.03 \\
\hline SL043 & $50,559,704$ & $50,299,706$ & 6.98 & 0.02 & 98.06 & 94.19 & 47.03 \\
\hline
\end{tabular}




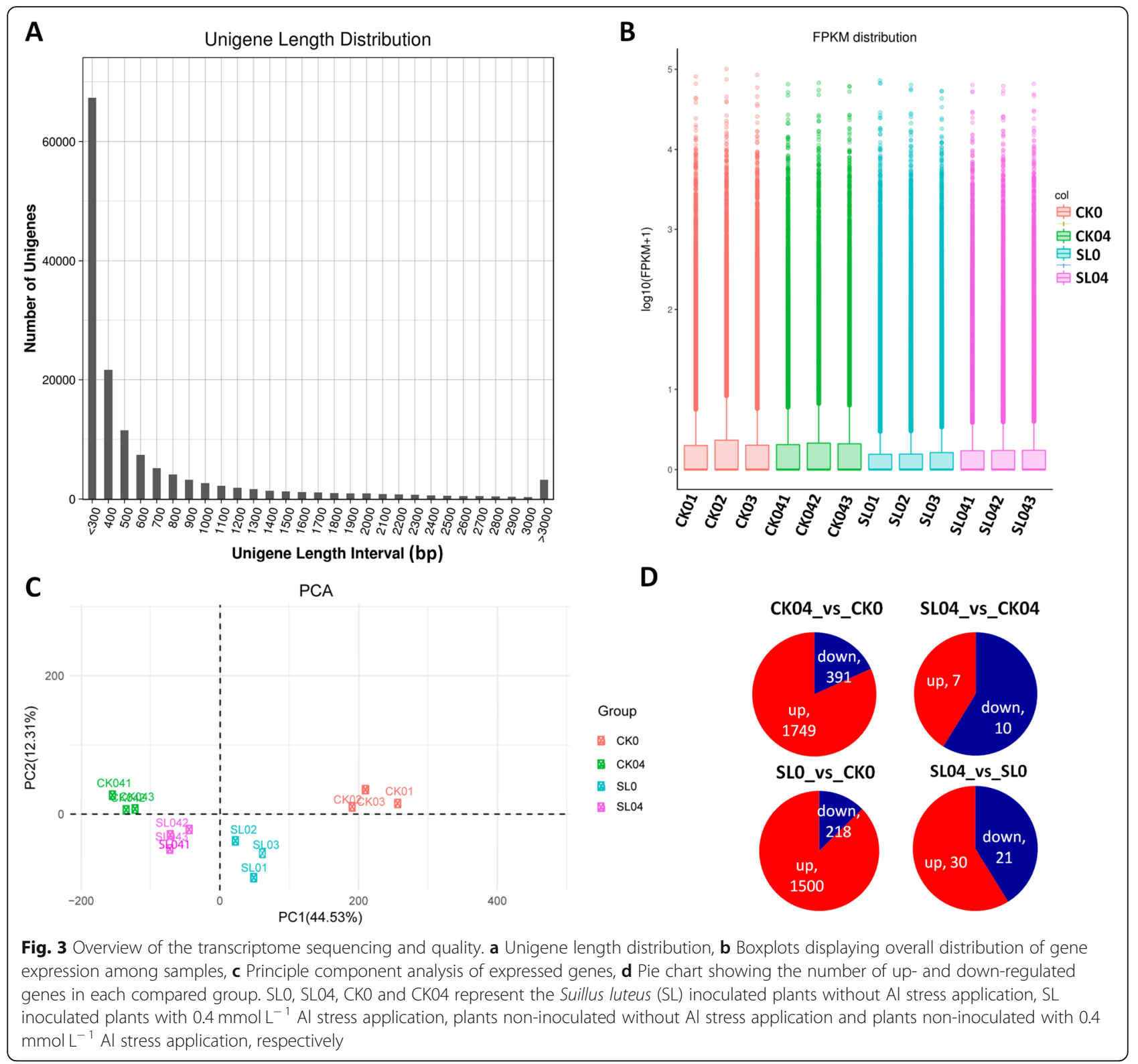

Table 3 Statistics of the unigene annotation

\begin{tabular}{lll}
\hline Database & Number of unigenes & Percentage (\%) \\
\hline Annotated in NR & 56,449 & 38.81 \\
Annotated in SwissProt & 35,420 & 24.35 \\
Annotated in PFAM & 28,256 & 19.43 \\
Annotated in GO & 26,522 & 18.24 \\
Annotated in KEGG & 11,912 & 8.19 \\
Annotated in all Databases & 137 & 0.09 \\
Annotated in at least one Database & 97,440 & 67 \\
Total Unigenes & 145,434 & 100 \\
\hline
\end{tabular}


DEGs involved in $\mathrm{Al}$ stress response without SL inoculation, while SL04_vs_SL0 provides DEGs involved in Al stress response with SL inoculation. The conspicuous difference in the number of DEGs between these two comparisons (2140 vs 51) indicates that fewer genes were transcriptionally altered by $\mathrm{Al}$ under SL inoculation as compared to conditions without SL inoculation. This confirms that SL inoculation confers $\mathrm{Al}$ stress tolerance in P. massoniana.

\section{Core conserved genes regulated by Al stress independently of SL inoculation}

We compared the DEGs induced by $\mathrm{Al}$ without SL inoculation (CK04_vs_CKO) and with SL inoculation (SL04_vs_ SLO) in order to identify the core regulated DEGs altered by $\mathrm{Al}$ stress. As shown in Fig. 4a, nine core DEGs were detected of which, six DEGs (TRINITY_DN51554_c0_g1, TRINITY_DN43208_c1_g2, TRINITY_DN41634_c0_g1, TRI NITY_DN47204_c2_g1, TRINITY_DN48891_c3_g1, TRIN $\left.I T Y \_D N 50963 \_c 0 \_g 5\right)$ displayed similar patterns of regulation between CK04_vs_CK0 and SL04_vs_SL0 (Fig. 4b), indicating that these genes are essential for $\mathrm{Al}$ response in $P$. massoniana. The gene TRINITY_DN48891_c3_g1 was not functionally annotated, implying it may be an Al-responsive gene specific to $P$. massoniana. In contrast, we identified three other genes (TRINITY_DN41897_c0_g1 (cox1), TRIN ITY_DN38714_c0_g5 (cox3) and TRINITY_DN47195_c0_g2 $(N d 1)$ ), which displayed opposite patterns of regulation between CK04_vs_CK0 and SL04_vs_SL0 (Fig. 4b). The strong up-regulation of these genes in SLO4_vs_SL0 may indicate a tolerance mechanism, which the control plants failed to trigger under $\mathrm{Al}$ stress (CKO4_vs_CKO).

\section{Candidate genes conferring Al stress tolerance induced by SL inoculation}

Since $P$. massoniana seedlings tolerate well $\mathrm{Al}$ stress under SL inoculation, we considered the specifically regulated genes in SL04_vs_SL0 as candidate genes imparting $\mathrm{Al}$ stress tolerance. In total, $42 \mathrm{DEGs}$ were identified in SL04_vs_SLO (Fig. 4a, Table 4) but they were not significantly altered in the non-inoculated plants under $\mathrm{Al}$ stress (CK04_vs_CK0). Most of the detected genes are involved in antioxidative response, hormone signaling and more importantly plant pathogen infection responses. This shows that prior to exposure to $\mathrm{Al}$ stress, SL inoculated plants have an enhanced immune system and ROS scavenging machinery, which may be instrumental for promptly responding to $\mathrm{Al}$ stress. Besides, several unannotated DEGs were detected, representing interesting gene resources for future functional characterization.

\section{qRT-PCR validation of selected genes}

We selected 11 various candidate genes involved in $\mathrm{Al}$ stress response in $P$. massoniana to validate their expression levels using qRT-PCR. The gene Actin2 was used as internal control for expression normalization. The qRTPCR result showed that the expression levels of all selected genes were significantly altered by $\mathrm{Al}$ stress (Fig. 5). In addition, qRT-PCR results were strongly correlated with the RNA-seq report $\left(R^{2}=0.8\right)$, indicating that the interpretation of the RNA-seq report in this study is reliable.

\section{Discussion}

Suillus luteus inoculation confers aluminum stress tolerance in $P$. massoniana seedlings

By applying Aluminum (Al) concentrations higher than $0.1 \mathrm{mM}$, Liu and Liu [47] found that P. massoniana growth is significantly reduced. In this study, we observed a significant inhibition of $P$. massoniana growth under $0.4 \mathrm{mM} \mathrm{Al}$ (Fig. 1; Table 1). Since high Al concentrations $(>1 \mathrm{mM})$ were reported in forest soils in southern China [30, 55], it is evident that P. massoniana suffers from Al toxicity in the field. Various

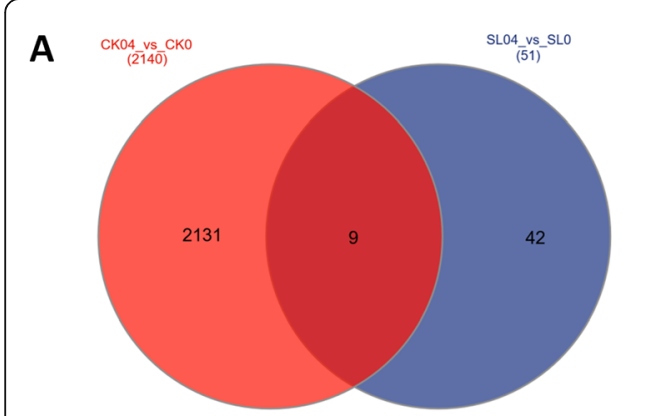

\begin{tabular}{|c|c|c|}
\hline Gene ID & CKO4_vs_CKO & SLO4_vs_SLO \\
\hline TRINITY_DN41897_c0_g1 & -3.1274 & 3.9965 \\
\hline TRINITY_DN38714_c0_g5 & -2.2639 & 4.0236 \\
\hline TRINITY_DN47195_c0_g2 & -2.8165 & 2.8887 \\
\hline TRINITY_DN51554_c0_g1 & -2.6077 & -3.7178 \\
\hline TRINITY_DN43208_c1_g2 & 4.0964 & 4.1018 \\
\hline TRINITY_DN41634_c0_g1 & 4.2372 & 6.9543 \\
\hline TRINITY_DN47204_c2_g1 & 4.3313 & 4.4661 \\
\hline TRINITY_DN48891_c3_g1 & 4.5276 & 5.3086 \\
\hline TRINITY_DN50963_c0_g5 & 5.5887 & 4.2093 \\
\hline
\end{tabular}

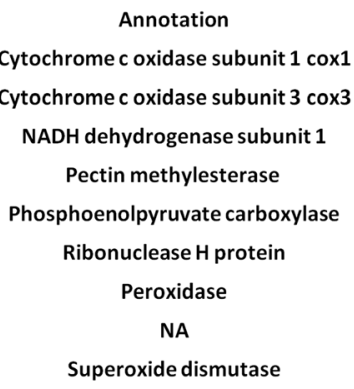

Fig. 4 Identification of candidate genes imparting Al stress tolerance in Suillus luteus (SL) inoculated Pinus massoniana seedlings. a Venn diagram depicting the number of shared and specific differentially expressed genes (DEGs) induced by Al without SL inoculation (CKO4_Vs_CKO) and with SL inoculation (SL04_vs_SLO). b Heatmap showing the log2 fold change of nine core DEGs between CK04_Vs_CKO and SL04_Vs_SLO. Gene names highlighted in red are those with an opposite pattern of regulation between the two groups. SLO, SL04, CKO and CK04 represent the SL inoculated plants without Al stress application, SL inoculated plants with $0.4 \mathrm{mmol} \mathrm{L}^{-1} \mathrm{Al}$ stress application, plants non-inoculated without Al stress application and plants non-inoculated with $0.4 \mathrm{mmol} \mathrm{L}^{-1}$ Al stress application, respectively 
Table 4 Genes specifically regulated in SL inoculated plants in response to Al stress

\begin{tabular}{|c|c|c|}
\hline Gene ID & Log2 Fold Change SL04/SL0 & Annotation \\
\hline TRINITY_DN50947_c2_g1 & -10.045 & pre-mRNA-processing protein $40 \mathrm{C}$-like \\
\hline TRINITY_DN42182_C1_g1 & -6.626 & NA \\
\hline TRINITY_DN41191_CO_g1 & -6.3241 & Pectin methylesterase (PME) \\
\hline TRINITY_DN40212_CO_g1 & -5.8947 & NA \\
\hline TRINITY_DN36359_C1_g1 & -5.8146 & Olee1-like protein \\
\hline TRINITY_DN36491_CO_g1 & -5.6695 & NA \\
\hline TRINITY_DN40533_CO_g1 & -4.9629 & DUF538 \\
\hline TRINITY_DN47888_CO_g1 & -4.792 & DUF3799 \\
\hline TRINITY_DN44356_c0_g1 & -3.6987 & Pathogenesis-related protein \\
\hline TRINITY_DN53237_c4_g1 & -2.957 & Subtilisin-like protease SBT5.6 \\
\hline TRINITY_DN10972_C0_g1 & -2.5905 & NA \\
\hline TRINITY_DN44990_CO_g2 & -2.5865 & Ubiquitin \\
\hline TRINITY_DN49726_Cl_g1 & -2.4029 & C2 domain \\
\hline TRINITY_DN49726_C1_g2 & -2.3392 & NA \\
\hline TRINITY_DN44727_C0_g4 & -2.2457 & UDP-rhamnose:rhamnosyltransferase 1 \\
\hline TRINITY_DN44741_C1_g1 & -2.1912 & NA \\
\hline TRINITY_DN50117_CO_g5 & -2.1671 & Downy mildew resistant 6 oxygenase \\
\hline TRINITY_DN47573_c2_g4 & -2.0719 & NA \\
\hline TRINITY_DN46639_C1_g3 & -2.0478 & NA \\
\hline TRINITY_DN50628_C0_g3 & -2.0341 & DUF674 \\
\hline TRINITY_DN47580_c3_g1 & 2.0214 & Protein phosphatase $2 \mathrm{C}$ \\
\hline TRINITY_DN40477_CO_g2 & 2.1501 & Superoxide dismutase (SOD) \\
\hline TRINITY_DN52128_c2_g4 & 2.2455 & Chaperone protein ClpB1-like protein \\
\hline TRINITY_DN48901_CO_g1 & 2.3314 & $60 S$ acidic ribosomal protein P0 \\
\hline TRINITY_DN46679_C1_g3 & 2.3589 & NA \\
\hline TRINITY_DN49138_CO_g1 & 2.5076 & Plant protein 1589 of unknown function (A_thal_3526) \\
\hline TRINITY_DN45082_c2_g2 & 2.6635 & NA \\
\hline TRINITY_DN47946_C1_g6 & 3.0243 & NA \\
\hline TRINITY_DN50109_C1_g2 & 3.131 & NA \\
\hline TRINITY_DN51142_c2_g1 & 3.2377 & Serine carboxypeptidase-like 40 \\
\hline TRINITY_DN48446_CO_g1 & 3.299 & Peroxidase (POD) \\
\hline TRINITY_DN51077_CO_g4 & 3.3457 & LRR receptor-like serine/threonine-protein kinase \\
\hline TRINITY_DN38876_CO_g1 & 3.4286 & NA \\
\hline TRINITY_DN50590_CO_g1 & 3.5695 & Superoxide dismutase (SOD) \\
\hline TRINITY_DN49159_c3_g1 & 4.3167 & Indole-3-acetic acid (IAA) \\
\hline TRINITY_DN47375_C2_g1 & 4.7598 & NBS-LRR protein G6229 \\
\hline TRINITY_DN49087_C1_g2 & 4.8788 & TIR-NBS-LRR protein \\
\hline TRINITY_DN39211_CO_g1 & 7.2334 & Multidrug and toxic compound extrusion (MATE) \\
\hline TRINITY_DN45197_CO_g1 & 7.3014 & Gluthatione $\mathrm{S}$ transferase (GST) \\
\hline TRINITY_DN47067_c5_91 & 8.1155 & Peroxidase (POD) \\
\hline TRINITY_DN49617_C1_g1 & 10.6606 & Chaperone protein ClpB1 \\
\hline TRINITY_DN44453_CO_g2 & 21.5957 & NA \\
\hline
\end{tabular}




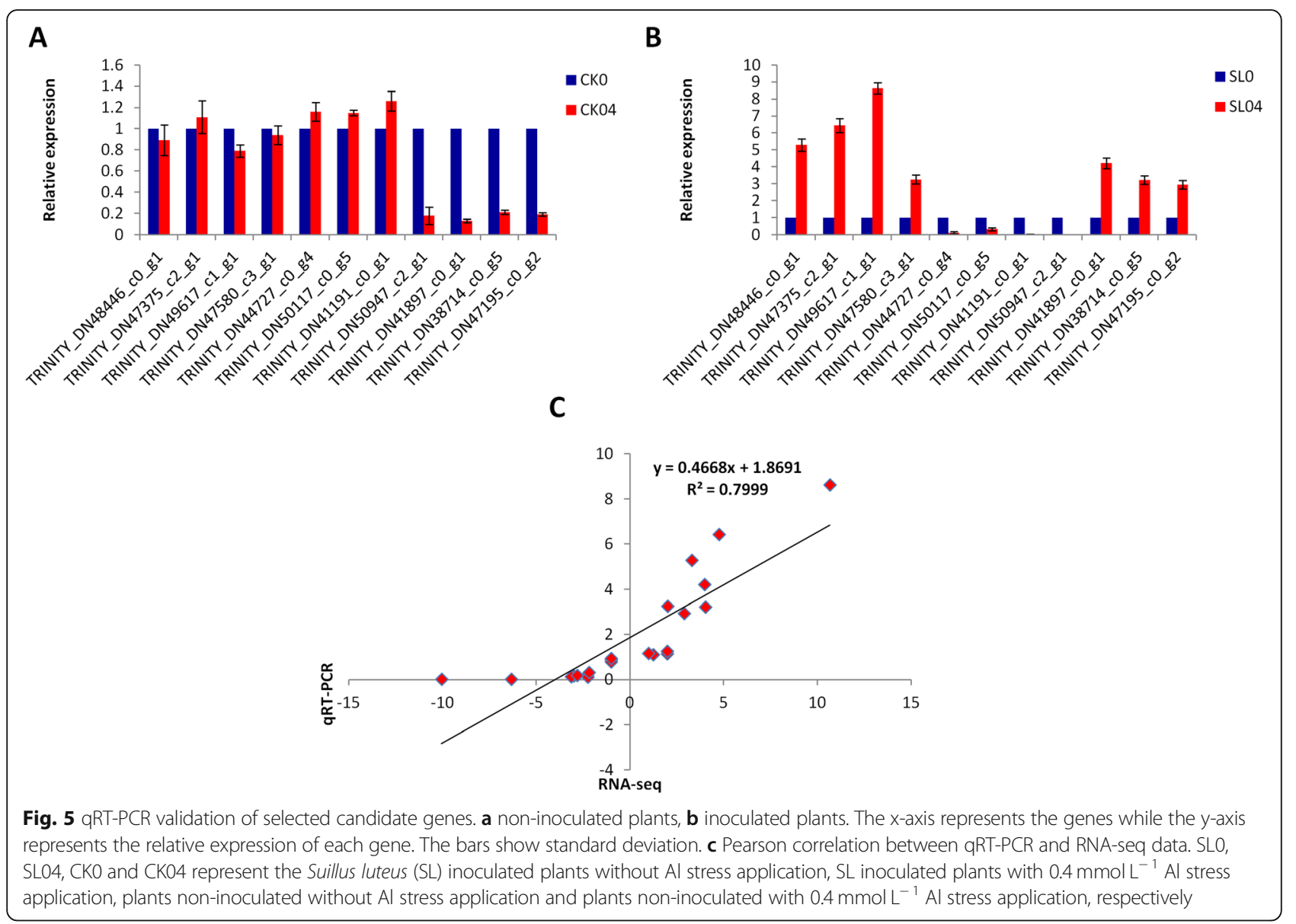

ectomycorrhizal fungi have been shown to improve Pinus growth performance and tolerance to diverse biotic and abiotic stresses, including Al toxicity [4, 6, 25-28]. Suillus luteus (SL) is an ectomycorrhizal fungus widely found in Pinus plantations [56, 57]. It has been reported that SL can grow in adverse soil conditions such as soils with high salinity, water scarcity, high $\mathrm{Mg}, \mathrm{Zn}, \mathrm{Cd}, \mathrm{Pb}, \mathrm{Ni}, \mathrm{Al}[6,50$, $51,56,58,59]$. In particular, numerous studies have demonstrated that SL is an Al tolerant fungal species [60-63] and it can facilitate the regeneration and plantation of Pinus seedlings in $\mathrm{Al}$ contaminated areas. The results of this study fully corroborate previous findings because our SL inoculated $P$. massoniana plants tolerated well $\mathrm{Al}$ stress (Fig. 1). Yamamoto et al. [37] revealed that high amount of $\mathrm{Al}$ induces excessive reactive oxygen species (ROS) accumulation in cells, which ultimately leads to cell death. The weak malondialdehyde content coupled with strong antioxidant enzymes activity in SL inoculated plants (Fig. 2) suggests that SL limits ROS related damages in $P$. massoniana. This was further confirmed by the significantly lower number of DEGs found in SL inoculated plants as compared to non-inoculated plants under $\mathrm{Al}$ stress (Fig. 3d) [64, 65]. In future studies, it will be important to clarify the physiological mechanisms of $\mathrm{Al}$ tolerance induced by SL inoculation in P. massoniana. For example, by determining $\mathrm{Al}$ content in various plant tissues before and after $\mathrm{Al}$ treatment with and without SL inoculation, we will be able to understand how SL affects $\mathrm{Al}$ uptake by P. massoniana.

\section{New gene resources for improving Al tolerance in $P$. massoniana}

The mechanisms of $\mathrm{Al}$ response including, reduced $\mathrm{Al}$ uptake and detoxification of absorbed $\mathrm{Al}$ in the symplasm have been well studied in plants [66]. Several related genes with various biological functions such as stress response, membrane transporter, organic acid metabolism, cell wall modification, signaling, hormones, transcription factors have been identified [45, 66-69]. In this study, we identified nine core genes playing diverse functions in response to $\mathrm{Al}$ stress in $P$. massoniana independently of SL inoculation (Fig. 4). The up-regulation of the genes TRINITY DN47204_c2_g1 (SOD) and TRINITY_DN50963_c0_g5 (POD) showed that activation of antioxidant enzymes is a basic response to $\mathrm{Al}$ stress in P. massoniana. The secretion of organic acids such as citrate, malate and oxalate from the roots detoxifies soil $\mathrm{Al}$ [70]. The strong up-regulation of the gene TRINITY_DN43208_c1_g2 
(phosphoenolpyruvate carboxylase) which is involved in oxalate metabolism suggests that this mechanism is conserved in $P$. massoniana as demonstrated in other plant species $[71,72]$. We noticed the down-regulation of a pectin methylesterase gene (PME, TRINITY_DN51554_c0_g1) which is known to be involved in cell wall structure and high level of PME correlates with high levels of $\mathrm{Al}$ adsorption. Therefore, $P$. massoniana tends to reduce $\mathrm{Al}$ adsorption by repressing the expression of the $P M E[72,73]$. Three core $\mathrm{Al}$ responsive genes (Cytochrome c oxidase $(c o x) 1, \operatorname{cox} 3$ and NADH dehydrogenase subunit 1 (Nad1)) associated with mitochondrial activity displayed opposite patterns between SL inoculated and non-inoculated plants. It is well documented that dysfunction of mitochondrial activity seriously impacts on plant fitness [74, 75] and Yamamoto et al. [76] evidenced that Al stress disrupts mitochondrial functions and provokes high accumulation of ROS in tobacco and pea. In this study, all these genes were up-regulated in SL inoculated plants while a strong down-regulation was observed in non-inoculated plants. We deduced that $\mathrm{Al}$ stress-induced shut down of mitochondrial activity may have led to high ROS accumulation and subsequently to the growth inhibition observed in non-inoculated plants. We propose these three genes, pending further validation, as marker genes for screening Al tolerant Pinus genotypes.

When engaged in symbiosis with tolerant ectomycorrhizal fungi, plant responses to $\mathrm{Al}$ are ameliorated since fungi can immobilize toxic $\mathrm{Al}$ into the mycorrhizal roots and surrounding soil environment and improve plant mineral nutrition to ensure normal growth [77]. However, genes mediated by ectomycorrhizal fungi in response to $\mathrm{Al}$ stress in host plants have been poorly investigated [23]. In this study, we identified 42 candidate genes unique to SL inoculated plants that may confer Al stress tolerance (Table 4). Most of these genes are involved in $\mathrm{Al}$ well known responsive pathways such as antioxidative response, hormone signaling, transporters and plant pathogen infection responses [66]. For example, peroxidase, gluthatione $\mathrm{S}$ transferase, multidrug and toxic compound extrusion, indole3-acetic acid, superoxide dismutase, protein phosphatase $2 \mathrm{C}$, pectin methylesterase have been reported to regulate $\mathrm{Al}$ response in plants $[45,54,72,73,78,79]$. A major finding in this study was the numerous genes involved in defense and plant pathogen infection pathway (Table 4). Similar to our results, Luo et al. [23] reported that ectomycorrhizal fungi induced high number of defensive and pathogen infection metabolites and genes under salinity stress in poplar. They concluded that ectomycorrhizal fungi boost the host immune system by priming roots for increased salt tolerance. We speculate that a similar mechanism was established in SL inoculated P. massoniana plants in this study and it helped seedlings to promptly and efficiently combat $\mathrm{Al}$ stress effects.

\section{Conclusions}

Inoculation of $P$. massoniana with the ectomycorrhizal fungus Suillus luteus (SL) improves seedling growth and confers Aluminum (Al) stress tolerance. Disruption of the mitochondrial functions through down-regulation of key genes such as cox1, $\operatorname{cox} 2$ and Nad1 is probably critical for $\mathrm{Al}$ inhibition of growth in non SL inoculated seedlings. Therefore, strategies to activate these genes under $\mathrm{Al}$ stress in $P$. massoniana should be further investigated. We also identified several candidate genes including some unannotated genes that may play cardinal roles in $\mathrm{Al}$ stress tolerance. Functional characterization of these gene resources will provide necessary tools for engineering $\mathrm{Al}$ tolerant Pinus plants with less dependence on ectomycorrhizal fungi.

\section{Method}

\section{Plant material, ectomycorrhizal fungus and stress treatment}

P. massoniana Lamb. was used as plant material in this study. The seeds were collected in November 2018 from a superior provenance tree (20 years) planted in Duyun City, Guizhou Province, China. The ectomycorrhizal fungus species Suillus luteus (SL), identified as an aggressive colonizer to P. massoniana [56], was used for plant inoculation. The fruiting part of the fungus was collected from was collected from $P$. massoniana pure plantation in Longli Forest Farm (N26 $28^{\prime} 01^{\prime \prime}$, E107 $\left.00^{\prime} 37^{\prime \prime}\right)$, Longli County, Guiyang City, Guizhou Province, China. The formal identification of the plant material and fungus was undertaken by the corresponding author of this article (Professor Guijie Ding). Plant material is available at the National base of $P$. massoniana $\left(\mathrm{N} 26^{\circ} 169^{\prime} \sim 26^{\circ} 170^{\prime}\right.$, E107 $623^{\prime} \sim 107^{\circ} 624^{\prime}$ ) at Maanshan forest farm, Duyun City, Guiyang City, Guizhou Province and a voucher specimen has been deposited at Guizhou Botanical Garden, Guiyang, China, under the accession number: xgnk-2003a12. No permission was necessary to collect such samples. Inoculum preparation and plant inoculation were performed following detailed descriptions in works of $\mathrm{Yu}$ et al. [6]. Seedlings were raised from February to July 2019 and 6-months old seedlings inoculated with S. luteus (inspected for successful mycorrhization) were used as test materials while 6-months old seedlings without inoculation were used as control.

The experiment was carried out in a greenhouse with light intensity of $600-800 \mu \mathrm{mol} \mathrm{m}{ }^{-2} \mathrm{~s}^{-1}$, relative humidity of $55 \%$, photoperiod of $16 \mathrm{~h}, 25^{\circ} \mathrm{C}$ at light and $18^{\circ} \mathrm{C}$ in the dark. The quartz sand was rinsed, sterilized in an autoclave (pressure $0.14 \mathrm{MPa}, 121^{\circ} \mathrm{C}$ ) for $2 \mathrm{~h}$, and then loaded into plastic pots $(21 \mathrm{~cm} \times 15 \mathrm{~cm} \times 18.5 \mathrm{~cm})$. Uniform seedlings were selected and transplanted into the pots. They were kept under normal growth conditions for 2 weeks by pouring frequently $1 / 2$ Hoagland nutrient 
solution. Then, the stress treatment started. Four treatments were set, namely 2 inoculated treatments SLO (0 mmol L $\left.{ }^{-1} \mathrm{Al}^{3+}\right)$, SL04 $\left(0.4 \mathrm{mmol} \mathrm{L}^{-1} \mathrm{Al}^{3+}\right)$ and 2 noninoculated treatments CK0 $\left(0 \mathrm{mmol} \mathrm{L}^{-1} \mathrm{Al}^{3+}\right)$, CK04 $\left(0.4 \mathrm{mmol} \mathrm{L}^{-1} \mathrm{Al}^{3+}\right)$ following descriptions of Liu and Liu [47]. For Aluminum (Al) stress, $\mathrm{Al}$ was added to total Hoagland nutrient solution in the form of anhydrous $\mathrm{AlCl}_{3}$ and the $\mathrm{pH}$ value was adjusted to $4.1 \pm 0.1$ [47] with $0.1 \mathrm{M}$ diluted $\mathrm{HCl}$ or $\mathrm{NaOH}$ to maintain acidic conditions. In order to maintain the $\mathrm{Al}$ activity, 0.5 $\mathrm{mmol} \mathrm{L}^{-1} \mathrm{CaCl}_{2}$ was added into the nutrient solution at the same time to avoid interaction between $\mathrm{Al}$ ion and solution ions. The treatment solution was poured once a week. Each treatment was repeated five times containing 15 pots each, with three plants per pot. Plants were collected on the 60th day after the induction of $\mathrm{Al}$ stress to measure the growth and physiological parameters in the four groups. In addition, we randomly selected three plants from different replicates in each treatment and needle samples were collected for transcriptome analysis. Samples were frozen in liquid nitrogen and stored at $80^{\circ} \mathrm{C}$ for further use.

\section{Measurement of morphological parameters}

Ten plants per treatment were selected from the five replicates (two plants per replicate), gently shaken to remove the quartz sand on the root surface, and carefully washed with running water. Root quantitative traits were measured from scanned images from a desktop scanner (EPSON Perfection V800 Photo, CA, USA) using the WinRHIZO Pro software (Regent Instruments Inc., Quebec, Canada). Seedling height was measured with a vernier caliper; the root and shoot fresh weights were recorded separately using an electric balance (Type: ML 204; Mettler Toledo Company, Greifensee, Switzerland; measurement accuracy $0.0001 \mathrm{~g}$ ). Samples were dried at $80^{\circ} \mathrm{C}$ to constant weight and the dry weights were recorded.

\section{Determination of SOD, POD, soluble sugar and MDA}

The content of Malondialdehyde (MDA) and the activities of superoxide dismutase (SOD) and peroxidase (POD) in the needle samples from the four treatments were determined in five replicates separately according to the instructions provided by kits (COMIN, Keming Biotechnology Co. Ltd., Suzhou, China). The content of MDA was expressed as $\mu \mathrm{mol} \mathrm{g}^{-1} \mathrm{FW}$. SOD and POD activities were expressed as units per gram fresh weigh $\left(\mathrm{Ug}^{-1} \mathrm{FW}\right)$. One unit (U) of SOD activity was defined as the activity of SOD when the inhibition of the xanthine oxidase coupling reaction system was $50 \%$, while one unit $(\mathrm{U})$ of POD activity was defined as the variation of 0.01 in $\mathrm{A} 470$ per $\mathrm{mL}$ reaction system.

\section{Statistical analysis}

All data were statistically analyzed with Minitab18 software $(P<0.05)$. Tukey's test based on analysis of variance (ANOVA) was chosen to analyze the data.

\section{RNA extraction, CDNA library construction and transcriptome sequencing}

Experiments are conducted following standard procedures of Shanghai Applied Protein Technology, Co., Ltd. (APT, Shanghai, China). Briefly, total RNAs were extracted from 12 needle samples with RNAprep Pure Plant Kit (TIANGEN, Beijing, China). Concentrations of the samples were quantified by a NanoDrop $2000 \mathrm{C}$ spectrophotometer (Thermo Fisher Scientific). To get high quality RNA, samples were tested on 1\% agarose gel electrophoresis for the integrity of RNA and DNA contamination. For accurate detection of RNA integrity, Agilent 2100 Bioanalyzer was used. RNA quantification was performed using Qubit RNA Assay Kit in Qubit 2.0 Flurometer (Life Technologies, Carlsbad, CA, USA). Next, RNA integrity was checked by the RNA Nano 6000 Assay Kit of the Agilent Bioanalyzer 2100 system (Agilent Technologies, Santa Clara, CA, USA). For cDNA synthesis, a total $1 \mu \mathrm{g}$ RNA for each sample was treated with DNase I to eradicate the genomic DNA and then used as a template for reverse transcription (QuantiTect Reverse Transcription Kit, Qiagen, China).

We added fragment buffer to break into short segments using short segment RNA as template. Sequencing libraries was created using NEB Next Ultra RNA Library Prep Kit following manufacturer's instructions. The index codes were added to each sample. Briefly, the mRNA was purified from $3 \mu \mathrm{g}$ total RNA of each of three replicate using poly- $\mathrm{T}$ oligo-attached magnetic beads and then broken into short fragments to synthesize first strand cDNA. The second strand cDNA synthesis was subsequently performed using DNA Polymerase I and RNase H. PCR was carried out with Phusion High Fidelity DNA polymerase using universal PCR primers and index $(x)$ primer. Finally, 12 paired-end cDNA libraries with an insert size of 300 bp were constructed for transcriptome sequencing and sequenced on Illumina HiSeq 4000 platform (Illumina Inc., San Diego, USA) at Shanghai Applied Protein Technology, Co., Ltd. (APT, Shanghai, China).

De novo assembly, functional annotation, expression analysis The clean reads were obtained after trimming adapter sequences, removal of low quality (containing $>50 \%$ bases with a Phred quality score $<20$ ) and reads with unknown nucleotides (more than 1\% ambiguous residues $\mathrm{N}$ ) using the FastQC tool (http://www.bioinformatics.babraham.ac. $\mathrm{uk} /$ projects/fastqc/). Analysis of the GC content distribution was performed. Transcriptome assembly was performed 
using Trinity r20140717 [80] and employing paired-end method. For hierarchical clustering, Corset was used (https://code.google.com/p/corset-project/). The longest cluster sequence was obtained by clustering with Corset hierarchy as unigene for subsequent analysis. The assembled unigenes were then annotated in various databases such as KEGG using KAAS (E-value $<1.0 \times$ $10^{-10}$ ), GO using Blast2GOv2.5 (E-value $<1.0 \times 10^{-6}$ ), PFAM using HMMER3.0 (E-value <0.01), Swissprot using BLAST 2.6.0+ (E-value $\left.<1.0 \times 10^{-5}\right)$ and NR using BLAST 2.6.0+ $\left(\right.$ E-value $\left.<1.0 \times 10^{-5}\right)$.

The sequenced reads were compared with the unigene library using Bowtie2 [81], and the level of expression was estimated in combination with RSEM [82]. The gene expression level was determined according to the fragments per kilobase of exon per million fragments mapped (FPKM) method. The Principal component analysis was performed in $\mathrm{R}$ v2.3.0. The read count was normalized and EdgeR Bioconductor package [83], was used to determine the differential expression genes (DEGs) between groups with the $\mid \log 2$ fold change $\mid \geq 2$ and false discovery rate (FDR) correction set at $P<0.05$ [54]. GO enrichment analysis was performed using the topGO method based on the wallenius noncentral hypergeometric distribution with $P<0.05$ [84]. KEGG pathway enrichment analysis of the DEGs was done using KOBAS2.0 [85]. The FDR correction was employed $(P<$ $0.05)$ to reduce false positive prediction of enriched $G O$ terms and KEGG pathways.

\section{Gene expression analysis using quantitative real PCR}

In order to confirm the gene expression levels obtained from the RNA-seq, a qRT-PCR analysis was performed on RNA extracted from needle samples as described previously [86]. The qRT-PCR was conducted on a Roche Lightcyler 480 instrument using the SYBR Green Master Mix (Vazyme, Vazyme Biotech Co. Ltd., Nanjing, China) following the manufacturer's protocol. The gene Actin2 was used as internal control. Specific primer sequences for selected genes were designed with PrimerPremier 5 and are presented in Table S1.

\section{Supplementary Information}

The online version contains supplementary material available at https://doi. org/10.1186/s12870-020-02719-3.

Additional file 1: Table S1. Primer sequences used for qRT-PCR in this study.

Additional file 2: Figure S1. GO enrichment analysis. SLO, CKO and CK04 represent the Suillus luteus (SL) inoculated plants without Al stress application, SL inoculated plants with $0.4 \mathrm{mmol} \mathrm{L}^{-1}$ Al stress application, plants non-inoculated without Al stress application and plants noninoculated with $0.4 \mathrm{mmol} \mathrm{L}^{-1} \mathrm{Al}$ stress application, respectively. Figure S2. KEGG enrichment analysis. SLO, CKO and CKO4 represent the Suillus luteus (SL) inoculated plants without Al stress application, plants non- inoculated without Al stress application and plants non-inoculated with $0.4 \mathrm{mmol} \mathrm{L}^{-1}$ Al stress application, respectively.

\section{Abbreviations}

Al: Aluminum; SL: Suillus luteus; ROS: Reactive oxygen species;

MDA: Malondialdehyde; SOD: Superoxide dismutase; POD: Peroxidase; FPKM: Fragments per kilobase of exon per million fragments mapped; PCA: Principal component analysis; DEG: Differentially expressed genes; FDR: False discovery rate

\section{Acknowledgements}

Not applicable.

\section{Authors' contributions}

HL: experimental set up, RNA-seq data analysis and manuscript writing; HC and KL: physiological and biochemical indicators analysis; GD: qRT-PCR validation, RNA-seq data analysis manuscript writing; QR: Study conception, funding acquisition, supervision, revision of the manuscript. All authors have read and approved the manuscript.

\section{Funding}

This work was funded by the National Key Research and Development Program of China (No. 2017YFD06003002) and the Science and Technology Foundation of Guizhou Province ([2016]1144). The funders had no role in the design and conduct of the study; collection, management, analysis, and interpretation of the data; preparation, review, or approval of the manuscript; and decision to submit the manuscript for publication.

\section{Availability of data and materials}

The datasets supporting the conclusions of this article are available in the NCBI Bioproject repository, accession number: PRJNA636599. The data will be released upon publication of this manuscript.

Ethics approval and consent to participate

Not applicable.

Consent for publication

Not applicable.

\section{Competing interests}

The authors declare that they have no competing interests.

\section{Author details}

${ }^{1}$ College of Forestry, Guizhou University/Institute for Forest Resources \& Environment of Guizhou, Guiyang 550025, Guizhou, China. ${ }^{2}$ Guizhou Botanical Garden, Guiyang 550004, Guizhou, China.

Received: 15 June 2020 Accepted: 25 October 2020

Published online: 16 November 2020

\section{References}

1. Luo YH, Sun DJ, Lin JY, Guo WF, Lu LH, Wen YG. Effect of close-to-nature management on the natural regeneration and species diversity in a masson pine plantation. Acta Ecol Sin. 2013;33(19):6154-62

2. Dou X, Deng Q, Li M, Wang W, Zhang Q, Cheng X. Reforestation of Pinus massoniana alters soil organic carbon and nitrogen dynamics in eroded soil in South China. Ecol Eng. 2013;52:154-60.

3. Wang Y, Ding G. Physiological responses of mycorrhizal Pinus massoniana seedlings to drought stress and drought resistance evaluation. Chin J Appl Ecol. 2013;24:639-45.

4. Zhang, T., Wen, X. \& Ding, G. Ectomycorrhizal symbiosis enhances tolerance to low phosphorous through expression of phosphate transporter genes in masson pine (Pinus massoniana). Acta Physiol Plant 39, 101 (2017). https://doi.org/10.1007/s11738-017-2392-y.

5. Wang $X$, Lu L, Xing H, Zeng J, Xie Y, Cai D, Liu X, Zhang X. Effects of closeto-nature conversion on Pinus massoniana plantations at different stand developmental stages. Trop Conserv Sci. 2018;11:1-16.

6. Yu P, Sun Y, Huang Z, Zhua F, Sun Y, Jiang L. The effects of ectomycorrhizal fungi on heavy metals' transport in Pinus massoniana and bacteria 
community in rhizosphere soil in mine tailing area. J Hazard Mater. 2020; 381:121203.

7. Jiang Z., Zhang S.Y. 2003. China's plantation forests for sustainable wood supply and development. http://www.fao.org/3/XII/0955-B4.htm, accessed on 21 May 212020.

8. Yang H, Wang S, Zhang J, Fan B, Zhang W. Biomass and nutrients of Pinus massoniana plantations in southern China: Simulations for different managing practices. J Food Agric Environ. 2011;9:689-93.

9. Deng X, Zhang L, Lei P, Xiang W, Yan W. Variations of wood basic density with tree age and social classes in the axial direction within Pinus massoniana stems in Southern China. Ann Forest Sci. 2014;71(4):505-16. https://doi.org/10.1007/s13595-013-0356-y.hal-01101774 Springer Verlag/EDP Sciences.

10. Zhang, P., He, Y., Feng, Y., De La Torre R., Jia H., Tang J., Cubbage F. An analysis of potential investment returns of planted forests in South China. New For 50, 943-968 (2019). https://doi.org/10.1007/s11056-019-09708-x.

11. Cui $Y$, Xie H, Wang J. Potential biomedical properties of Pinus massoniana bark extract. Phytother Res. 2005;19:34-8. https://doi.org/10.1002/ptr.1619.

12. Ma H, Lai F, Xie H, Wang J, Wang H. Involvement of the Bcl-2 family members in Pinus massoniana bark extract induced apoptosis in HeLa cells. Phytother Res. 2008:22:1472-6.

13. Duke JA, Ayensu ES. Medicinal Plants of China. 1985;2(705 S):1300 Strichzeichnungen: Reference Publ., Inc. Algonac. Michigan. ISBN 0-91726620-4.

14. Wu D, Li S, Yang D, Cui Y. Effects of Pinus massoniana bark extract on the adhesion and migration capabilities of HeLa cells. Fitoterapia. 2011;82:1202-5.

15. Rincón, A., Álvarez, I. \& Pera, J. Ectomycorrhizal fungi of Pinus pinea L. in northeastern Spain. Mycorrhiza 8, 271-276 (1999). https://doi.org/10.1007/ s005720050245.

16. Rincón A, Alvarez IF, Pera J. Inoculation of containerized Pinus pinea $\mathrm{L}$ seedlings with seven ectomycorrhizal fungi. Mycorrhiza. 2001;11:265-71.

17. Parladé J, Pera J, Alvarez IF. Inoculation of containerized Pseudotsuga menziesii and Pinus pinaster seedlings with spores of five species of ectomycorrhizal fungi. Mycorrhiza. 1996;6:237-45.

18. Duñabeitia MK, Hormilla S, Garcia-Plazaola Jl, Txarterina K, Arteche U, Becerril JM. Differential responses of three fungal species to environmental factors and their role in the mycorrhization of Pinus radiata. Mycorrhiza. 2004;14:11-8.

19. Lu N, Yu M, Cui M, Luo Z, Feng Y, Cao S, Sun Y, Li Y. Effects of different Ectomycorrhizal fungal inoculates on the growth of Pinus tabulaeformis seedlings under greenhouse conditions. Forests. 2016;7:316.

20. Garbaye J. The role of ectomycorrhizal symbiosis in the resistance of forests to water stress. Outlook Agr. 2000;29:63-9.

21. Kohler J, Hernández JA, Caravaca F, Roldán A. Induction of antioxidant enzymes is involved in the greater effectiveness of a PGPR versus AM fungi with respect to increasing the tolerance of lettuce to severe salt stress. Environ Exp Bot. 2009;65:245-52.

22. Lehto T, Zwiazek JJ. Ectomycorrhizas and water relations of trees: a review. Mycorrhiza. 2011;21:71-90.

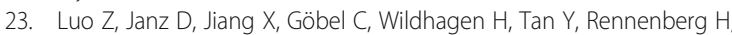
Feussner I, Polle A. Upgrading root physiology for stress tolerance by Ectomycorrhizas: insights from metabolite and transcriptional profiling into reprogramming for stress anticipation. Plant Physiol. 2009;151:1902-17. https://doi.org/10.1104/pp.109.143735.

24. Hao, Z., Xie, W., \& Chen, B. (2019). Arbuscular Mycorrhizal Symbiosis affects plant immunity to viral infection and accumulation. Viruses, 11(6), 534 https://doi.org/https://doi.org/10.3390/v11060534.

25. Zhu, J., Li, F., Xu, M., Kang H., Wu X. The role of ectomycorrhizal fungi in alleviating pine decline in semiarid sandy soil of northern China: an experimental approach. Ann For Sci 65, 304 (2008). https://doi.org/10.1051/ forest:2008007.

26. Wang J, Huang $Y$, Jiang $X Y$. Influence of ectomycorrhizal fungi on absorption and balance of essential elements of Pinus tabulaeformis seedlings in saline soil. Pedosphere. 2011;21(3):400-6.

27. Kipfer T, Wohlgemuth T, van der Heijden MGA, Ghazoul J, Egli S (2012) Growth response of drought-stressed Pinus sylvestris seedlings to singleand multi-species inoculation with Ectomycorrhizal Fungi. PLoS One 7(4): e35275. https://doi.org/10.1371/journal.pone.0035275.

28. Yin D, Halifu S, Song R, Qi J, Deng X, Den J Effects of an ectomycorrhizal fungus on the growth and physiology of Pinus sylvestris var mongolica seedlings subjected to saline-alkali stress J For Res 2020, 31, 781-788. https://doi.org/10.1007/s11676-019-01007-7.

29. Ulrich B (1989). Effects of acidic precipitation on forest ecosystems in Europe. In: Adriano et al. (eds.). Acidic Precipitation, Biological and Ecological Effects. New York: Springer, 189-272.

30. Zhang J, Lyu Z, Shao S, Li F, Yang S, Song W, Li W, Li S. Effects of aluminum toxicity induced by acid deposition on pine Forest ecosystem in Longli of Guizhou Province, Southwestern China. Chin Geogra Sci. 2016;26:495-507. https://doi.org/10.1007/s11769-015-0763-0.

31. Ulrich B. Effects of acidic precipitation on forest ecosystem in Europe. In: Adriano DC, Johnson AH, editors. Acidic Precipitation, vol. 2. Berlin: SpringVerlay; 1989. p. 189-272.

32. Rengel Z. Handbook of soil acidity. New York: Marcel Dekker Inc; 2003. p. 496.

33. Li W, Johnson CE. Relationships among pH, aluminum solubility and aluminum complexation with organic matter in acid forest soils of the northeastern United States. Geoderma. 2016;271:234-42.

34. Von Uexkuell HR, Mutert E. Global extent, development and economic impact of acid soils. Plant Soil. 1995;171:1-15.

35. Ryan PR, DiTomaso JM, Kochian LV. Aluminium toxicity in roots: an investigation of spatial sensitivity and the role of the root cap. J Exp Bot. 1993;44:437-46. https://doi.org/10.1093/jxb/44.2.437.

36. Kochian LV, Pineros MA, Hoekenga OA. The physiology, genetics and molecular biology of plant aluminum resistance and toxicity. Plant Soil. 2005;274:175-95.

37. Yamamoto $Y$, Kobayashi Y, Matsumoto H. Lipid peroxidation is an early symptom triggered by aluminium, but not the primary cause of elongation inhibition in pea roots. Plant Physiol. 2001;125:199-208.

38. Kochian LV, Hoekenga OA, Piñeros MA. How do crop plants tolerate acid soils? Mechanisms of aluminum tolerance and phosphorous efficiency. Annu Rev Plant Biol. 2004;55:459-93.

39. Ma JF. Syndrome of aluminum toxicity and diversity of aluminum resistance in higher plants. Int Rev Cytol. 2007;264:225-52.

40. Brunner, I., \& Sperisen, C. (2013). Aluminum exclusion and aluminum tolerance in woody plants. Front Plant Sci, 4, 172. https://doi.org/10.3389/ fpls.2013.00172.

41. Sasaki T, Yamamoto Y, Ezaki B, Katsuhara M, Ahn SJ, Ryan PR, et al. A wheat gene encoding an aluminum-activated malate transporter. Plant J. 2004;37: 645-53. https://doi.org/10.1111/j.1365-313X.2003.01991.X.

42. Hoekenga OA, Maron LG, Piñeros MA, Cançado GM, Shaff J, Kobayashi Y, et al. AtALMT1, which encodes a malate transporter, is identified as one of several genes critical for aluminum tolerance in Arabidopsis. Proc Natl Acad Sci USA. 2006;103:9738-43. https://doi.org/10.1073/pnas.0602868103.

43. Furukawa J, Yamaji N, Wang H, Mitani N, Murata Y, Sato K, et al. An aluminum-activated citrate transporter in barley. Plant Cell Physiol. 2007:48: 1081-91. https://doi.org/10.1093/pcp/pcm091.

44. Magalhaes JV, Liu J, Guimarães CT, Lana UGP, Alves VMC, Wang YH, et al. A gene in the multidrug and toxic compound extrusion (MATE) family confers aluminum tolerance in sorghum. Nat Genet. 2007:39:1156-61. https://doi.org/10.1038/ng2074

45. Bian M, Zhou M, Sun D, Li C. Molecular approaches unravel the mechanism of acid soil tolerance in plants. Crop J. 2013;1:91-104.

46. Schaedle M, Thornton FC, Raynal DJ, Tepper HB. Response of tree seedlings to aluminum. Tree Physiol. 1989;5:337-56.

47. Liu R, Liu H. Effect of acidity and aluminum on the growth of Pinus massoniana seedlings. Acta Bot Sin. 1995;37(2):154-8 (in Chinese).

48. Grisel, N., Zoller, S., Künzli-Gontarczyk, M., Lampart, T., Münsterkötter, M., Brunner, I., Bovet, L., Métraux, J. P., \& Sperisen, C. (2010). Transcriptome responses to aluminum stress in roots of aspen (Populus tremula). BMC Plant Biol, 10, 185. https://doi.org/10.1186/1471-2229-10-185.

49. Göransson A, Eldhuset TD. Effects of aluminium on root growth and nutrient uptake of Betula pendula seedlings. Physiol Plant. 1987;69:193-9.

50. Kasuya CM, Muchovej R, Muchovej J. Influence of aluminum on in vitro formation of Pinus caribaea mycorrhizae. Plant Soil. 1990;124:73-7. https://doi.org/10.1007/BF00010933

51. Ahonen-Jonnarth, U., Göransson, A., Finlay, R. D. (2003). Growth and nutrient uptake of ectomycorrhizal Pinus sylvestris seedlings in a natural substrate treated with elevated Al concentrations. Tree Physiol, 23(3), 157-167. https://doi.org/10.1093/treephys/23.3.157.

52. Sheoran $S$, Thakur $V$, Narwal S, Turan R, Mamrutha HM, Singh V, Tiwari $V$, Sharma I. Differential activity and expression profile of antioxidant enzymes 
and physiological changes in wheat (Triticum aestivum L.) under drought. Appl Biochem Biotechnol. 2015;177(6):1282-98.

53. Foyer $\mathrm{CH}$, Noctor $\mathrm{G}$. Redox homeostasis and antioxidant signaling: a metabolic interface between stress perception and physiological responses. Plant Cell. 2005;17(7):1866-75.

54. Chen $\mathrm{H}$, Lu C, Jiang H, Peng J. Global transcriptome analysis reveals distinct aluminum-tolerance pathways in the Al-accumulating species Hydrangea macrophylla and marker identification. PLoS One. 2015;10(12):e0144927. https://doi.org/10.1371/journal.pone.0144927.

55. Guo J, David Vogt R, Zhang X, Zhang Y, Seip HM, Xiao J, Tang H. Aluminium Mobilization from Acidic Forest Soils in Leigongshan Area, Southwestern China: Laboratory and Field Study. Arch Environ Contam Toxicol. 2006;51:321-8.

56. Huang, J., Nara, K., Lian, C., Zong, K., Peng, K., Xue, S., \& Shen, Z. (2012). Ectomycorrhizal fungal communities associated with Masson pine (Pinus massoniana Lamb.) in Pb-Zn mine sites of central South China. Mycorrhiza 22(8), 589-602. https://doi.org/10.1007/s00572-012-0436-0.

57. Hayward, J., Horton, T. R., Pauchard, A., \& Nuñnez, M. A. (2015). A single ectomycorrhizal fungal species can enable a Pinus invasion. Ecology, 96(5), 1438-1444. https://doi.org/10.1890/14-1100.1.

58. Colpaert, J.V., Vandenkoornhuyse, P., Adriaensen, K. And Vangronsveld, J. (2000), Genetic variation and heavy metal tolerance in the ectomycorrhiza basidiomycete Suillus luteus. New Phytol 147: 367-379. https://doi.org/10. 1046/j.1469-8137.2000.00694.x.

59. Huang, J., Han, Q., \& Li, J. (2018). Soil propagule bank of ectomycorrhizal fungi associated with Masson pine (Pinus massoniana) grown in a manganese mine wasteland. PLoS One, 13(6), e0198628. https://doi.org/ https://doi.org/10.1371/journal.pone.0198628.

60. Thompson GW, Medve RJ. Effects of aluminum and manganese on the growth of ectomycorrhizal fungi. Appl Environ Microbiol. 1984 Sep;48(3):556-60.

61. Leski T, Rudawska M, Kieliszewska-Rokicka B. Intraspecific aluminium response in Suillus luteus (L.) s.f. gray., an ectomycorrhizal symbiont of scots pine. Acta Soc Bot Pol. 1995;64:97-105. https://doi.org/10.5586/asbp.1995.014.

62. Li H, Huang JG, Yuan L. Influence of aluminum and manganese on the growth, nutrient uptake and the efflux by Ectomycorrhizal Fungi. Environ Sci. 2013;34(1):315-20.

63. Wang MX, Yuan L, Huang JG, Zhou ZF. Al3+ Absorption and Assimilation by Four Ectomycorrhizal Fungi. Environ Sci. 2015;36(9):3479-85. https://doi.org/ 10.13227/j.hjkx.2015.09.045

64. Wang, L., Li, D., Zhang, Y., Gao, Y., Yu, J., Wei, X., \& Zhang, X. (2016). Tolerant and susceptible sesame genotypes reveal waterlogging stress response patterns. PLoS One, 11(3), e0149912. https://doi.org/10.1371/journal.pone. 0149912.

65. Dossa, K., Li, D., Wang, L., Zheng, X., Liu, A., Yu, J., Wei, X., Zhou, R., Fonceka, D., Diouf, D., Liao, B., Cissé, N., \& Zhang, X. (2017). Transcriptomic, biochemical and physio-anatomical investigations shed more light on responses to drought stress in two contrasting sesame genotypes. Sci Rep, 7(1), 8755. https://doi.org/10.1038/s41598-017-09397-6.

66. Bojórquez-Quintal, E., Escalante-Magaña, C., Echevarría-Machado, l., \& MartínezEstévez, M. (2017). Aluminum, a friend or foe of higher plants in acid soils. Front Plant Sci, 8, 1767. https://doi.org/10.3389/fpls.2017.01767.

67. Guo P, Qi YP, Huang WL, et al. Aluminum-responsive genes revealed by RNA-Seq and related physiological responses in leaves of two Citrus species with contrasting aluminum-tolerance. Ecotoxicol Environ Saf. 2018;158:21322. https://doi.org/10.1016/j.ecoenv.2018.04.038.

68. Guo P, Qi YP, Cai YT, Yang TY, Yang LT, Huang ZR, Chen LS. Aluminum effects on photosynthesis, reactive oxygen species and methylglyoxal detoxification in two Citrus species differing in aluminum tolerance. Tree Physiol. 2018;38(10):1548-65. https://doi.org/10.1093/treephys/tpy035.

69. Guo P, Qi Y-P, Yang L-T, Lai N-W, Ye X, Yang Y, Chen L-S. Root adaptive responses to aluminum-treatment revealed by RNA-Seq in two Citrus species with different aluminum-tolerance. Front Plant Sci. 2017;8:330 https://doi.org/10.3389/fpls.2017.00330.

70. Zheng SJ, Ma JF, Matsumoto H. High aluminum resistance in buckwheat. I. Al-induced specific secretion of oxalic acid from root tips. Plant Physiol. 1998;117:745-51.

71. Begum HH, Osaki M, Watanabe T, Shinano T. Mechanisms of aluminum tolerance in Phosphoenolpyruvate carboxylase transgenic Rice. J Plant Nutr. 2009:32(1):84-96. https://doi.org/10.1080/01904160802531035.

72. Xu L-M, Liu C, Cui B-M, Wang N, Zhao Z, Zhou L-N, Huang K-F, Ding J-Z, Du $\mathrm{H}-\mathrm{M}$, Jiang W, Zhang S-Z. Transcriptomic responses to aluminum (Al) stress in maize. J Integr Agric. 2018;17(9):1946-58.
73. Schmohl NJ, Fisahn J, Horst WJ. Pectin methylesterase modulates aluminium sensitivity in Zea mays and Solanum tuberosum. Physiol Plant. 2000;109:419-27.

74. Mansilla, N., Racca, S., Gras, D. E., Gonzalez, D. H., \& Welchen, E. (2018). The complexity of mitochondrial complex IV: an update of cytochrome C oxidase biogenesis in plants. Int J Mol Sci, 19(3), 662. https://doi.org/10. 3390/ijms19030662.

75. Fromm, S., Senkler, J., Eubel, H., Peterhänsel, C., \& Braun, H. P. (2016). Life without complex I: proteome analyses of an Arabidopsis mutant lacking the mitochondrial NADH dehydrogenase complex. J Exp Bot, 67(10), 3079-3093. https://doi.org/10.1093/jxb/erw165.

76. Yamamoto Y, Kobayashi Y, Devi SR, Rikiishi S, Matsumoto H. Aluminum toxicity is associated with mitochondrial dysfunction and the production of reactive oxygen species in plant cells. Plant Physiol. 2002;128(1):63-72.

77. Luo ZB, Wu CH, Zhang C, Li H, Lipka U, Polle A. The role of ectomycorrhizas in heavy metal stress tolerance of host plants. Environ Exp Bot. 2014;108:47-62.

78. Kumari M, Taylor GJ, Deyholos MK. Transcriptomic responses to aluminum stress in roots of Arabidopsis thaliana. Mol Gen Genomics. 2008;279:339-57.

79. Mattiello L, Kirst M, da Silva FR, Jorge RA, Menossi M. Transcriptional profile of maize roots under acid soil growth. BMC Plant Biol. 2010;10:196.

80. Grabherr MG, Haas BJ, Yassour M, Levin JZ, Thompson DA, Amit I, Adiconis $X$, Fan L, Raychowdhury R, Zeng Q, et al. Full-length transcriptome assembly from RNA-Seq data without a reference genome. Nat Biotechnol. 2011;29: 644-52. https://doi.org/10.1038/nbt.1883.

81. Langmead, B., Salzberg, S. Fast gapped-read alignment with bowtie 2. Nat Methods 9, 357-359 (2012). https://doi.org/10.1038/nmeth.1923.

82. Li B, Dewey CN. RSEM: accurate transcript quantification from RNA-Seq data with or without a reference genome. BMC Bioinformatics. 2011;12:323. https://doi.org/10.1007/978-1-4939-0512-63.

83. Robinson, M. D., McCarthy, D. J., \& Smyth, G. K. (2010). edgeR: a bioconductor package for differential expression analysis of digital gene expression data. Bioinformatics, 26(1), 139-140. https://doi.org/10.1093/ bioinformatics/btp616.

84. Young MD, Wakefield MJ, Smyth GK, Oshlack A. Gene ontology analysis for RNA-seq: accounting for selection bias. Genome Biol. 2010;11:R14.

85. Xie C, Mao X, Huang J, Ding Y, Wu J, Dong S, Kong L, Gao G, Li C-Y, Wei L. KOBAS 2.0: a web server for annotation and identification of enriched pathways and diseases. Nucleic Acids Res. 2011;39:W316-22. https://doi.org/ 10.1093/nar/gkr483.

86. Dossa K, Mmadi MA, Zhou R, Zhang T, Su R, Zhang Y, Wang L, You J, Zhang $X$. Depicting the core transcriptome modulating multiple abiotic stresses responses in sesame (Sesamum indicum L.). Int. J Mol Sci. 2019;20:2-22. https://doi.org/10.3390/ijms20163930.

\section{Publisher's Note}

Springer Nature remains neutral with regard to jurisdictional claims in published maps and institutional affiliations.

Ready to submit your research? Choose BMC and benefit from

- fast, convenient online submission

- thorough peer review by experienced researchers in your field

- rapid publication on acceptance

- support for research data, including large and complex data types

- gold Open Access which fosters wider collaboration and increased citations

- maximum visibility for your research: over $100 \mathrm{M}$ website views per year

At BMC, research is always in progress.

Learn more biomedcentral.com/submissions 